\title{
Semantic Peculiarity of Word moda [moda] 'fashion, custom, vogue' in Russian dialects
}

\author{
T. Leontyeva \\ Russian State Vocational Pedagogical University \\ RSVPU \\ Yekaterinburg, Russia \\ leotany@mail.ru
}

\begin{abstract}
The article presents results of studying semantics of the word moda $[$ moda] 'fashion, custom, vogue' in Russian dialects. It is shown that in Russian folk dialects this word has received semantic elaboration, different from the system of its meanings in the literary language. It is written by collectors of Russian vocabulary in such meanings as "custom/habit, model / sample, costume / apparel, respect, law, appropriateness, measure" and others. Some of these meanings do not exist in the Russian literary language. Semantic components of the word модa are analyzed. It is proved that they are different in the literary word and its dialectic analogues. Those studying the fashion phenomenon and lexical representatives specify the following constituent signs: the social aspect, collective and mass character, model character, the social and regulative function. Those studying the fashion phenomenon in its various manifestations and lexical representatives specify the following constituent signs. During three ages of functioning in the Russian language, the word system of the Russian language. Moreover, a word, borrowed from the foreign language, was adopted by Russian folk dialects, where it received semantic development different from the system of meanings of the literary language. Then sems 'new', 'temporary, transient', 'alien' got leveled in the word модa. In a folk culture, moda is presented as a custom, a fact of daily reality, customary due to a long time of existence and reiteration.
\end{abstract}

Keywords-ethno-linguistics; semantics; Russian dialects; fashion; custom

\section{INTRODUCTION}

Humanities and social sciences have come to mutual consent in interpreting conception of модa [fashion] as a social phenomenon. The meaning "individual habit of a person" could be considered as an exception, (E.g. Он взял моду не ужинать [He has fallen into habit of having no supper]), but a habit is also caused by social environment. Those studying the fashion phenomenon in its various manifestations and lexical representatives specify the following constituent signs:

- social aspect: "Fashion may be understood as the most superficial and the most deep of social mechanisms" [1: 169];

- collective and mass character which also result in conventional character of fashion and its identifying potential:
"Fashion has a global character, participants of fashion feel their affiliation to a vast indefinite whole" [2: 86];

- model character, an ability to be a standard, and value character, as an object, which is recognized to be a value and attracts attention of society - an idea, rule, style of garment, manner to express ideas, way to act, especial or-ganization of life, etc. - appear to be key components of fashion "Fashion is a social phenomenon of imitating authorities, a standard of the beautiful which is a mirror, reflecting situation in the society" [3: 6];

- social and regulative function: "Fashion in modern world is understood as one of the forms and mechanisms of social regulation and self-regulation of individual, group and mass human behavior" [4: 29]; "Historically fashion has developed from the custom. These two phenomena are united by their regulative function, they act as mechanisms of social regulation of behavior" [5: 46].

Above listed signs form a semantic main body of polysemantic модa [fashion], which is common for the majority of its meanings, including dialect ones. Yet this word is so differently used by speakers of the Russian literary language and in dialects that deep differences between modern urban consciousness and rural world outlook, becoming a piece of the past, are evident; especially in difference of contents of ideas, covered by nomination модa [fashion].

According to etymological dictionaries by M. Fasmer, P. Ya. Chernykh, A. Preobrazhensky, the word мoдa [fashion] is adopted from French mode or German Mode, and further descends to Latin modus 'measure (of object); a rule, an order, image, method'. In Russian this word is fixed since XVII century, and it is settled in dictionaries since 1731. It has correlations in other Slavonic languages - Ukranian, Belorussian, Bulgarian, Serbo-Croatian, Polish, Czech, and others [6: 636; 7: 537; 8: 544].

Let us present a brief list of meanings of the word модa, actual in the modern Russian literary language. Today most frequently (more than $70 \%$ of contexts, presented in Russian National Corpus) the word модa is applied to the sphere of fashion/vogue industry: models of garments, footwear, hair styles, accessories and also to aesthetics of interior designs, architecture and so on: 
- meaning 'fashionable style of clothes, show sample of fashionable / vogue garments' is preserved in steady / fixed combinations:

(1) модbl (Plural) [fashions / vogue] 'samples of garments, corresponding to latest fashion': На окнах расставленьл картинки парижских мод [Pictures of Paris fashionable garments were exhibited on windows]; Она переворошила все журналь мод) [She has stirred up all fashion/vogue magazines] [9: 1129-1130];

- meaning 'design, temporary preferences in cutting out and wearing clothes, hair style design, accessories and interior design' actualized in overwhelming majority of the word usage:

(2) мода 'fashion, a definite style in wearing clothes, interior design, etc.': А внутри тех палат сделано вельми хорошо, все итукатурно и письмами италианской модьь [And inside that palace, everything is very well designed with plaster work and drawings in Italian style] [10: 232];

(3) модa 'a short time supremacy of either style of the society in respect of clothes, articles of personal consumption, etc.': Вот, мой Онегин на свободе, Острижен по последней моде) [Here Onegin is out, his haircut is fashionably done] [9: 1128-1129].

The word мода [fashion] meaning 'temporary tendency in life organization, human behavior, ideology, speech, using articles of personal consumption' has quite various subjects of reference (denotats):

(4) На Западе в моде консультации психотерапевта [In Western countries psycho-therapeutic consultancy is in fashion] - magazine «100\% of Health», 2003 [11];

(5) В начале девяностых спортивный образ жизни вошёл в модy [In early 1990-s sporting way of life came into fashion] - «Business-Journal», 2003 [11];

(6) Создание новых компаний практически стало модой [In practice, starting new companies has become a fashion] «Weekly Magazine», 2003 [11];

(7) Среди руководителей больших компаний одно время 6 моде было объявить о грандиозных планах в области электронного бизнеса - такой проект символизировал их открытость и современность [For some time it was a fashion in among top managers of big companies to announce about huge plans in electronic business as such projects would symbolize their openness and up-to-dateness] - magazine «Expert-Internet», 2001 [11];

(8) Просто патриотизм нынче в моде [Patriotism is just in fashion now] - magazine «Commersant-Government», 2000 [11];

(9) С лёгкой руки Эдисона всевозможные тесты вошли в моду [With the help of Edison, various tests have become a fashion] - «Science and Life», 2009 [11].

Temporary events are usually meant and the speaker focuses on the stage of arising of new tastes or their loosing popularity.
The meaning 'popularity' may be considered as a nuance of the meaning 'temporary tendency' as it is offered in «Big Academic Dictionary» [9: 1128-1129]. Popularity is mainly connected with some personality, sometimes - with some piece of music, literature or arts:

(10) мода [fashion] 'about common acknowledgement, attention, fame at present time': Eсть, что и стихотворизь часто были в моде; Умной карла вошел в превеликую моду [Fact is that poets often were in fashion; A clever dwarf came into great fashion] [12: 240];

(11) мода 'common acknowledgement, attention, fame at present time': Моя “Пиковая дама” в большой моде; Недавно Хемницер как-то попал в моду; его стали издавать в Москве и в Петербурге [My Queen of Spades is in great fashion; Recently Hemniter somehow came into fashion; they started publishing his works in Moscow and Petersburg] [9: 1128-1129].

Thus, in the Russian literary language, the word модa [fashion] first of all means popularization of some new commercial product or a tendency in some sphere - Arts, politics, social communications and others. This understanding of fashion includes the following semantic components:

- novelty: "Fashion is understood as a collective imitation of regularly appearing novelties" [2: 86];

- alien element: lexem мода [fashion] has an implicit potential meaning 'alien, adopted, not of your own' [13: 63];

- influence of someone's charismatic individuality, as passion for the fashion have a certain source: fashion is "an extreme manifestation of taste, more individual, to be over soon, striking and usually annoying older and con-servative part of the society" [14:34];

- prestigiousness: following the fashion has a wish of a person to be a part of social elites as a moving force. A word combination модный человек [fashionable man / man of fashion]: "It is evident that self-identification "I am a fashionable man" results in a definite manner of behavior: a constant monitoring of fashion processes (for instance, reading fashionable magazines and books, watching advertised TVshows and pictures), adjusting fashionable novelties to own intellectual, cultural and financial means. Prestigious up-todatenesss is a content of fashion field" [15: 2].

Using the word модa, bearers of folk (rural) culture keep in mind different meanings. In a traditional society fashion was defined by focusing on collectivity and social norm a custom.

\section{MEANING OF WORD МОДА [FASHION] IN RUSSIAN DIALECTS}

Against a background of meanings of the word модa in various functional options of the Russian literary language, its semantic peculiarity in Russian dialects becomes noticeable. During comprehension of dialect materials, the author kept in mind possible errors in formulating meanings or selecting examples of word usage; this is why, the author based mainly on illustrative contexts in hand. 
Of course, Russian dialects speakers are aware of the word модa in its literary meanings connected with fashion industry and design styles:

(12) dial. don. Вот визала щулки, кохты, юпки и выгадывала моды из галавьл [So I was knitting stockings, jackets, skirts, and took design from my head] [16: 93];

(13) sth.-url. Не осталось у меня картинков, показала б я тебе моду на платье [I have no more pictures left, otherwise I would show you garments' designs] [17, vol. 2: 171];

(14) leningr. Сейчас переименовалась мода: девки стригутся, а парни волосы отрашивают [Now the fashion has changed: girls are cutting hair short, and young men grow hair up] [18, vol. 4: 446];

(15) kursk. A тогда была мода - белая кофта и черная была юбка под резинку [Then there was a fashion to wear white woman's jacket and a black skirt with elastic] - fron records of S. P. Pravednikov in Kursk region, 2000 [11].

The word мода [fashion] as a definition of a tendency in life organization is met in records of dialect speech, where on the first place are observations of informans over the use of some objects, technical devices and appliances for domestic use, materials, etc. in everyday life:

(16) sth.-url. Одно время мода на свиней была, много держали [At one time there was a fashion (tendency) for pigs, and people had many of them] [17, vol. 4: 387],

(17) arkh. А нынче ишь ведь холодильник, а раньще где их не было, этой моды-то не было, вот [And now, you see - a refrigerator! - and before there was no fashion for them] from records of A. K. Petrova in Arkhangelsk region, 1996 [11],

(18) onezh. не в моду '[not in fashion] 'it is not done': $B$ этажа теперь не в моду строить [Building two floors houses is not done now] [18, vol. 3: 244];

(19) kemer. моды не было [there was no fashion] 'there was no smth. as such.': Сахару моды не было, меду брали [There was no fashion for sugar, they used honey] [19: 19];

(20) kemer. отойти от моды [depart from fashion] 'become out-of-date, come out of use': Да плуг это. Валяется тут, отошел от моды [It is just a plough. It lies here, came out of use]; Лисапед теперь отошел от моды: все на мотоциклах ездют [A bicycle became out-of date, everyone is riding a motorbike] [19: 129];

(21) perm. быть в моде [be in fashion] 'to be accepted, usual, ordinary': A раньше корзинки были, старики-те плели. А щуас это не в моде [Before there were baskets, old people made them. Now it is not usual] [20: 177];

(22) don. Щас далблёнки из моди вылили [Now hollow boats have come out of use] [21:215];

(23) psk. A ра́ньшы марко́фку не́ была мо́ды се́ить, не́ была абьічая [Before it was not usual to sow carrots, it was not accepted]; Тяпе́рь мо́ды нет рука́м каси́ть [Now it is not usual to mow with hands]; Ф Пецо́рах вме́сте хо́дя в ба́ню и ба́бы и мужыки́, мо́да така́я [In Pechora men and women go to sauna together, as it is accepted]; Из дяре́вни в го́рат хади́mь и мо́ды не́ было [It was not usual to leave village for city] [22: 78].

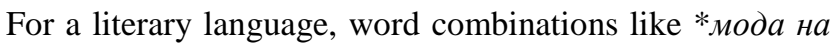
caxap [fashion for sugar] or *мода на лодки [fashion for boats] are impossible. Appearance of such combinations in dialect contexts is explained by the fact that here the word мода [fashion] means not popularity, but presence in everyday life, everyday customs and traditions.

Besides, in Russian dialects, the word мода [fashion] has preserved in meanings 'specimen, pattern of doing something, way to organize, model', and 'clothes, garments', which in the literary language are marked as obsolete, out-of date.

The meanings 'specimen, pattern of doing something, way to organize, model' are fixed in Russian dialects:

(24) yarosl. Окна нонешной моды, нынче деланы [Windows are of modern pattern, they are made nowadays] [23: 151];

(25) arkh. на другую моду [to another fashion] 'in another or a different way': Дома-то двужирные, двуконечные строили, а нынь всё на другую моду [They used to build houses with thicker walls and two ended (roof), and now everything is in a different way] [18, vol. 3: 244].

The word мода in the meaning 'sample, specimen' does not exist in dictionaries of the modern Russian language. Before it was functioning in texts of the XVII-XVIII centuries:

(26) мода 'device, type, model': Tут же есть ... плоская медная старинная, особой моды, пушка [Here one also has ... a flat, copper cannon of especial type] - 1712 [10: 232];

(27) мода 'sample, manner': Все крепости на одну моду [All the fortresses are built in the same manner] [8: 544];

(28) мода 'shape, sample, manner': Заложен корабль франиузской моды [A ship of French shape is laid] [12: 240].

In terms of expressing an idea of being a sample, a model, a standard', the meaning is of interest 'example':

(29) amur. проявить моду [to show / display fashion] 'to show/give an example': Это уж какой-то проявил моду подругому икры засолку делать [There was someone who gave an example of other way of salting caviar] [19: 157];

(30) tom. снять моду с кого, с чего [take fashion from smb., smth.] 'follow somebody's way or follow some sample' [24: 195].

The meaning 'attire, festive clothes, garment, dress' - in Russian folk dialects head dresses, sarafans (sundresses) and dresses are called модой [fashion]. In such case, a word receives compatibility that is peculiar to designations of articles of clothes - надевать моду, повязывать моду, ходить в моде [put on, cover head with, to wear fashion], and others:

(31) olon. мода 'kokoshnik (woman's hair dress of old style), woman's hair dress': Посмой, барин, у праздника, каку моду девки на голову наденут [You, master, have a look, 
what hair dresses girls will be covered with for the celebration] [24: 195];

(32) olon. мода 'unmarried girl's kerchief / headscarf, tied in an "urban" manner (around the head, knot and ends on the forehead)': Повязать моду [to cover head with headscarf] [24: 195];

(33) nizhegor. (iron.) Мода Павловна [Moda Pavlovna] 'woman's hair dress: a headscarf on cardboard base' [24: 195];

(34) arkh. мода [fashion] 'sarafan, sun-dress': Раньше все в таких модах ходили, в долгих сарафанах [In the past all (women) wore such clothes, long sun-dresses] [24: 195];

(35) rus. (buryat.) мода [fashion] 'a fashionable dress': Мод мы никаких не носили [We did not wear any fashionable dresses] [24: 195];

(36) yarosl. мода [fashion] 'woman's hair dress убор': Мода фаевая, черна, на кардонке, в складку, вроде шляпь, изпод моды - пукли [A nice fashion - black, on cardboard, pleated, like a hat, with curls set from under the hair dress] [23: 49].

This meaning «object / item» was peculiar to the word модa in the XVIII century. In the Modern Russian language dictionaries, the word in this meaning and only in plural is marked as 'obsolete':

(37) модbl (Plur.) [fashions] 'items of clothes of fashionable style; fashionable patterns': Mоды мужскаго и женскаго платья ... при гулянье ... увидятся [Items of gentlemen clothes and ladies' dresses of fashionable styles may be seen during the outdoor fete / festive outdoor gathering]; Госnодин и Госпожа Промоталовы навезли сюда много мод [Mr. and Mrs. Promotalovy have brought here lots of fashionable items]; $Я$ заеду на час кмоей торговке модами [I will spend an hour at my fashion items' seller] [12: 240];

(38) моды (Plur. obsollete) 'fashionable clothes and garments themselves': Дворянское [приданое] известно какое: одни только модыl, а денег много не спрашивайте [You know what a gentry's dowry is: only fashionable garments as trousseau, but don't ask for much money] [9: 1129-1130].

Let us address to dialect fixations, having no analogues in the literary language.

Meaning 'respect, authority / prestige', which the author finds possible to single out after the analysis of dialect speech records, is somehow brought into correlation with semem 'popularity'; yet in this case both indication of broader audience as a subject of recognition, and the idea of following popular standard are loosing their importance. Integration into socium, taking own place in it, and "social importance" come in the lead:

(39) Ну, только сейчас мы не в моде, старики [Well, it's only now that we, old people, are not in fashion] - from records of S.P. Pravednikov in Kursk region, 2000 [11].

One may also observe an accent displace from popularity to 'acceptance by society', "social attractiveness" of a young lady or man in their age group (in among rural youth) due to their decency, sociability, efficiency and other approved / favorable qualities:

(40) dial. perm.: (быть) на моде [be on fashion] 'be in fashion, in the centre of attention': Нет ребят-то никого, дак и мы на моде [There are no young men, so we are in fashion]; ural. не на моде [not in fashion] 'not sociable, awkward, clumsy': Она его незалюбела: он не на моде [She did not fall in love with him - he was awkward] [24: 195];

(41) perm. быть на моде [be on fashion] 'to be respected, demanded': Парень ко мне подошел, а он не на моде был я ногою топнула [A young man came at me, but he was not on fashion - I stamped my foot]; Которы гармонисты на моде были, а которые в стороне стояли [Some accordion players were in fashion, some others were standing outside] [25, vol. 1: 90].

\section{So, here fashion is a social recognition.}

The meaning 'custom as a part of a rite/ceremony, ritual, tradition of organizing life of socium', actualized in dialectic discourse, is partly close to the meaning 'temporary tendency in organizing life'. Yet in this case модa [fashion] is a social phenomenon which is notable for long standing, stability, tradition. An element of a ceremony is often meant:

(42) dial. sverdl. мода [fashion] 'custom': На второй день мы к им [сватам] едем - хозяйство смотреть. Это уж обязательно, така мода была [On second day we go to parents in law to inspect the estate. It was obligatory, there was such a custom] [26: 131];

(43) arkh. Раньше така была мода, нарядятся в наряды хорошие и пойдут по деревне, вот и ходят, гуляют [In the past there was a custom, to put on best clothes and stroll along the village, and so they did] - from records of A. L. Moroz, 1999 год [11];

(44) perm. Была мода такая: у невесты есть какое приданое, свадебжане надевают и по деревне казать богачество [There was a custom; if a fiancée has some trousseau, members of wedding train put it on and [stroll] along the village to show it] [25, vol. 3: 76];

(45) perm. Такая мода уж была - подругу невеста колотит [There was a custom - a fiancée was beating her helpmate] [25, vol. 3: 311];

(46) volog., leningr. Моду эту решают [уничтожают] о масленке кататься [They are destroying this custom - to drive around in a sledge during Shrovetide / Pancake week] [18, vol. 5: 520];

(47) novg. Прежде мода така была: парни садятся на колени к девкам и целуют кажду по кругу [In the past there was a custom; young men sat down on young ladies' knees and started kissing them on a go round] [27: 173];

(48) psk. Мо́да была́ ф каляду́ блины́́ пячи́ [There was a tradition to bake pancakes on Christmas week] [22: 78].

The word мода [fashion] in the meaning 'law, official establishment' is also fixed in dialect speech only: 
(49) psk. мода 'order, law': Ф калхози у нас моди нет, если абратишся, то толку не дабьешся [There is no order in our collective estate: if you apply (to the management), there will be no result]; Мódbl тако́й не́ была, штоп пе́ньсию дава́ли [There was no such law to pay pensions] [28: 280].

The meaning 'conformity to natural laws, appropriateness' is presented in a dictionary as a nuance of the previous meaning:

(50) psk. модa 'conformity to natural laws of life, development': Была $n$ такая мода: пажыл, да апять маладым [стал] [I wish there were such way of life: one lives his life, and then becomes young again] [28: 280].

And, finally, the meaning 'measure' is found in Russian dialects:

(51) perm. сверх моды на вериок [one inch above the measure] 'about smth. in big amount, in abundance': (В те годы-то не было экого в магазинах. $A$ в эти-то годы уж все появилось сверх моды на вериок [In years gone by there were no such (plenty of goods) in shops. And nowadays all the goods appeared in abundance] [25, vol. 2: 93].

This meaning coincides with Latin modus 'measure (of an object); rule, prescription, shape, method'.

A list of meanings mentioned-above does not reflect chronology of its semantic development: it is impossible to determine it, because affiliation of senses happened in various territories and various ways. During three ages of functioning in the Russian language, which is a comparatively short period in the history of the development of the language, the word мода [fashion] went steadily fitted to the word system of the Russian language which is confirmed by a variety of its meanings. Moreover, a word, borrowed from the foreign language, was adopted by Russian folk dialects, where it received semantic development different from system of meanings of the literary language. Idea of a sample, standard, according to which something is measured and reproduced, brought into circulation (items of clothes are produced, tastes and preferences of groups of people are shaped, human behavior is formed, ritual or everyday life of community is organized).

\section{CONCLUSION}

Difference between actual to a town-dweller idea of fashion as something changeable, fluctuating, modern (that is a deviation from normal), and relevant for folk, rural culture of explaining fashion as something steady, some custom, tradition or a norm proper was already underlined in linguistic literature [22: 78-79].

A critical degree of opposing fashion in epy traditional Russian rural socium and fashion in modern secular culture is displayed in comparing these ideas as per scales:

(1) "long standing - novelty",

(2) "steady /stable - changeable",

(3) "generally accepted - challenge to generally accepted",
(4) "naturally formed - artificially built",

(5) “of one's own - alien".

The first component of each opposing pair characterizes fashion as a custom (event of traditional folk culture), and the second one - fashion as novelty (event of a new culture, biased towards globalization, and dynamism of reorganization).

Comments to correlation of ideas «fashion» and «custom» are quite different: "The Russians have understanding of fashion as a custom, accepted as a model" [29: 421]; "There are more differences than likeness between fashion and custom. And the most significant of them is attitude towards innovations. If there is a constant change of cultural models, and time in fashion is discrete, then in custom, time is continuous and an item of culture, considered as a canon, is constantly reproduced in an unchangeable form" [5:46]. Pierre Larousse, the author of "Big Universal Dictionary of the XIX century" notes that fashion differs from custom, as a kind from gender [30: 358]. Sometimes lexical units модa [fashion] and обычай [custom] are even treated as antonyms: "Further on, when fashion was singled out into an independent social event, meanings of words мода [fashion] and обычай [custom] alienated from each other and they became explained as antonyms more and more often <... In modern explanatory dictionaries as a rule, fashion is alienated from custom" [31: 29].

And really, some part of dialect contexts shows that a dialect speaker gives name мода [fashion] to establishments to come into being. In other words, модa [fashion] is called a phenomenon, possessing qualities of novelty and alienness, compare to mutual projection of oppositions "old / new" and "belief / fashion" in saying: По старой вере, да по новой моде [According to old belief, but new fashion] [32:344]. As a обычай [custom] is understood a comparatively old social establishment, having properties of stability and even antiquity in mind of a language speaker. The new and while the alien, but being assimilated by many (модa [fashion]) is opposed to older own (обычай [custom]), though both are socially adopted patterns.

This likeness, as noted and adopted by Russian dialects' speakers, is gradually explains the possibility of mutual exchange of words мода [fashion] and обычай [custom], which means their functioning as synonyms when a ritual and peculiarity of everyday life organization are discussed. Then sems 'new', 'temporary, transient', 'alien' got leveled in the word мода [fashion].

This way, in a folk culture, fashion is presented as a custom, a fact of daily reality, customary due to a long time of existence and reiteration (reproduction ability), correlating to traditional organization of everyday life, agricultural works, performing rituals. For the comparison, let us remind that in a modern culture of big cities fashion is a deliberately formed, proceeding from society's demands temporary habit of an object, possessing customer's value by creating an attractive image. 


\section{Acknowledgment}

The study is supported by the Russian Science Foundation (project No. 16-18-02075 "Russian Society in the Mirror of Lexical Semantics").

\section{Abbreviations}

Amur. - Amur area

arkh. - Arkhangelsk area

volgogr. - Volgograd area

volog. - Vologda area

dial. - dialect

don. - Don area

iron. - ironical

kemer. - Kemerovo area

kursk. - Kursk area

lat. - Latin

leningr. - Leningrad area

Plur. - Plural

nizhegor. - Nizhny Novgorod area

novg. - Novgorod area

novosib. - Novosibirsk area

olon. - Olonets: recorded on the territory of Olonets prov-ince - an

administrative unit of Russian Empire with the centre in Petrozavodsk

onezh. - Onega area

perm. - Perm area

psk. - Pskov area

rus. (buryat.) - noted and fixed in Russian dialects on the territory of

Republic Buryatia

sverdl. - Sverdlovsk area

ural. - Ural region

obsol. - obsolete

sth.-url. - Southern Ural area

yarosl. - Yaroslavl' area

\section{References}

[1] J. Bodriyyar, "Symbolic exchange and death," Moskva: Dobrosvet, 2000.

[2] N. Zhuravleva, "Phenomenon of "fashionable" word: a dynamic aspect," Education. Science. Innovations: Southern measuring, vol. 11, pp. 83$89,2010$.

[3] I. Nikolaev, "Speech fashion in dis-course of Russian authority (from materials of President's message to Federal Assembly of RF 20002010," Bulletin of Perm State University. Series: Politology, vol. 2, pp. 5-20, 2011.

[4] N. Maryasova, "Changeable whim in everyday life: fashion as a mechanism of social regulation," Librarianship, vol. 24, pp. 27-29, 2011. (in Russian).

[5] A. Mustayoki and I. Vepreva, "What a fashionable word is: about parameters of fashion in language," Russian language abroad, vol. 2, pp. 45-62, 2006.

[6] M. Fasmer, "Etymological dictionary of Russian language", vol. 2. Moscow: Progress, 1986.

[7] P. Chernykh, "Historical and Etymological dictionary of modern Russian language", vol. 1. Moscow: Russian language, 1999.
[8] A. Preobrazhensky, "Etymological dictionary of Russian language", vol. 1. Moscow: State Publishers of foreign and national dictionaries, 1959.

[9] "Dictionary of modern Russian literary language", vol. 6. Moscow: Science, Leningrad: Academy of Sciences of USSR' Publishers, 1957.

[10] "Dictionary of Russian language of XI-XVII centuries", vol. 9. Moscow: Science, 1982.

[11] "Russian National Corpus". Available at: www.ruscorpora.ru.

[12] "Dictionary of Russian language of XVIII century", vol. 12. Leningrad: Science. Leningrad branch, Saint Petersburg: Science, St. Petersburg branch, 2001.

[13] T. Belitsa and O. Isachenko, "Expression of evaluation in expressions with a phrase "get a habit of doing smth," Bulletin of Novosibirsk State University. Series: History, Philology, vol. 8(2), pp. 62-67, 2009.

[14] V. Kostomarov, "Linguistic taste of the epoch: from observations over speech practice of mass-media," Saint Petersburg: Zlatoust, 1999.

[15] M. Chernyak, "Fashionable literature in context of trends and brands," Librarianship, vol. 24, pp. 25, 2011.

[16] BEDDK = "Big explanatory Dictionary of Don Cossacks". Moscow: Russian Dictionaries, Astrel, AST, 2003.

[17] N. Malecha, "Dictionary of dialects of Ural (Yajik) Cossacks", vol. 1-4. Orenburg, 2002-2003.

[18] A. Gerd (ed.), "Dictionary of Russian Dialects of Karelia and neighboring areas," vol. 1-6. Saint Petersburg: Saint Petersburg University Publishers, 1994-2005.

[19] A. Fyodorov (ed.), "Phraseological dictionary of Russian dialects of Siberia". Novosibirsk: Science, 1983.

[20] I. Rusinova (ed.), "Dictionary of Russian dialects of Northern part of Perm region," vol. 1. Perm: Permskij goudarstvennyj universitet, 2010.

[21] Rimma Kudryashova (ed.), "Dictionary of Don area Dialects of Volgograd Region," vol. 3. Volgograd: VGIPK RO Publishers, 2007.

[22] Yu. Gritskevich and V. Novikov, "Concept MODA in a dialect discourse," Bulletin of Pskov State Pedagogical University. Series: Social sciences and Humanities; psychological and pedagogical sciences, vol. 15, pp. 77-80, 2011.

[23] "Yaroslavl regional dictionary", vol. 6. Yaroslavl, 1987.

[24] Dictionary of Russian folk dialects, vol. 18. Moscow - Leningrad Saint Petersburg: Science, 1982.

[25] I. Podyukov (ed.), "Dictionary of Russian dialects od Southern preKama region", vol. 1-3. Perm: Perm State Humanitarian and Pedagogical University, 2010-2013.

[26] O. Vostrikov, "Traditional culture of the Urals: ethno-ideographic dictionary of Russian dialects of Sverdlovsk region", vol. 3. Yekaterinburg: Sverdlovsk regional Folklore centre, Urals' literature agency, 2000.

[27] "Novgorod regional dictionary". Saint Petersburg: Science, 2010.

[28] "Pskov regional dictionary with historical references," vol. 18. Leningrad: Leningrad University Publishers, 2006.

[29] I. Vepreva, "On linguistic reflection on vocabulary renovation of nowadays," Russian language today: active linguistic processes in the end of XX century, Moskva, 2003, pp. 402-421. (in Russian).

[30] P. Larousse, "Universal Dictionary of the XIX century: French, history, geography, mythology, bibliography, etc.,": 15 volumes, vol. V (XI), Paris: Administration du grand Dictionnaire universel, 1874.

[31] N. Maryasova, "Changeable whim in everyday life: fashion as a mechanism of social regulation," Librarianship, vol. 24, pp. 27-292011.

[32] V. Dahl, "Explanatory dictionary of living Great Russian language," vol. 2. Moscow: Russian Language, 1981. 